Research Article

\title{
Management of Domestic Marketing of Service Enterprises
}

\author{
Stoyan Radev KOEV ${ }^{1}$, Olena TRYFONOVA ${ }^{2}$, Lesia INZHYIEVSKA ${ }^{3}$, \\ Nataliia TRUSHKINA ${ }^{4}$ and Maryna RADIEVA ${ }^{5}$ \\ ${ }^{1}$ University of National and World Economy, Sofia, Bulgaria \\ ${ }^{2}$ National TU Dnipro Polytechnic, Dnipro, Ukraine \\ ${ }^{3}$ University of Educational Management, Kiev, Ukraine \\ ${ }^{4}$ Institute of Industrial Economics of NAS of Ukraine, Kiev, Ukraine \\ ${ }^{5}$ Melitopol Institute of Public and Municipal Administration of the "Classic Private University", \\ Melitopol, Ukraine
}

Correspondence should be addressed to: Stoyan Radev KOEV; koaduep@gmail.com

Received date:29 April 2019; Accepted date:16 July 2019; Published date: 3 September 2019

Academic Editor: Alena Fedorova

Copyright @ $\odot$ 2019. Stoyan Radev KOEV, Olena TRYFONOVA, Lesia INZHYIEVSKA, Nataliia TRUSHKINA and Maryna RADIEVA. Distributed under Creative Commons CC-BY 4.0

\begin{abstract}
A classification of contact personnel was proposed and a provision was developed on the assessment of its competencies and their impact on the potential of internal marketing, which provide for the construction of a graphical model that reflects the level of resource, process and strategic prerequisites for achieving the effectiveness of internal marketing of the enterprise, taking into account all stakeholders. A system was developed for monitoring the management of internal marketing of enterprises providing services, which involves the use of economic and mathematical modeling, decision-making support systems and the Internet technologies. This allows the owner of the enterprise to control management decisions affecting the internal marketing system, taking into account the role of contact personnel in order to ensure the effectiveness of running a business in a competitive environment. The analytical tools for diagnosing internal marketing of enterprises were improved, which, unlike the existing methodological approaches, allow, given the nature of services, assessing the level of satisfaction of three study objects at the same time: consumers, contact personnel and top managers of the enterprise.
\end{abstract}

Keywords: contact personnel, potential of internal marketing, diagnostics, stakeholders, consumer services

Cite this Article as: Stoyan Radev KOEV, Olena TRYFONOVA, Lesia INZHYIEVSKA, Nataliia TRUSHKINA and Maryna RADIEVA (2019)," Management of Domestic Marketing of Service Enterprises", IBIMA Business Review, Vol. 2019 (2019), Article ID 681709, DOI: 10.5171/2019.681709 


\section{Introduction}

The modern dynamic development of science and technology, the production of high-tech goods and the latest services in the context of the diversity of the socioeconomic environment are accompanied by a search for new ways to establish and maintain long-term relations of the manufacturer with all contact audiences. That is why the focus of marketing is a consumer educated and armed with modern technologies who can not only enter into dialogue with the manufacturer, but also manage this dialogue. In this regard, service providers should be aware that the client becomes a partner in creating value and added value and so does time its consumer, and therefore, change in its role influences the marketing strategy and core competencies of the contact personnel. Proceeding from this, modern enterprises of the service industry to achieve success and victory in the competition are not yet enough to use the tools of traditional marketing. In order to ensure long-term mutually beneficial relations in the chain of participants in the creation of a market proposal: "owner - top management personnel - client", it is particularly relevant and necessary to use the tools of internal marketing and modern means of marketing communications.

The problem of finding a highly qualified, motivated, competent, customer-oriented and adaptive employee is relevant for service rendering enterprises. The diversification of enterprise activities in the industry market, the intensification of competition, the rapid change in the needs and the requirements of demanding consumers encourage top management to optimize and improve personnel policy. Education, professional competence, work experience are no longer sufficient features of an applicant for employment. The growth of the human factor in the operating activities of service enterprises leads to an increase in the requirements of the applicant, with the focus on his/her diverse personal qualities and creative potential. The use of such an integrated approach to the search, recruitment, selection, adaptation, training and partnerships building with personnel will affect the quality of services, the service process, the additional services and the image of the service rendering enterprise.

We must also remember that personnel meeting all the requirements and requests of the employing enterprise can lay down its own demands.

A high salary is not just enough for a highclass specialist, because he/she always has an alternative in employment, he/she needs appropriate conditions an environment that will allow realizing his/her creative potential fully, and individual values will be harmoniously combined with corporate. In this aspect, the classic employment and personnel training take a back seat. The internal environment and the potential of the enterprise, the factors of relationships building within the "manager-personnelclient" system, the corporate culture and the employee prevail, and these categories are the object of the internal marketing research. One of the main tasks of the internal marketing is to systematically optimize the processes occurring within the enterprise.

Contact personnel focused on individualization of the proposal in achieving maxim um satisfaction of the demands and needs of the customer as the main link is aimed at the marketing functions performance and building relationships between all contact audiences of the enterprise.

The performance of the enterprise rendering services, the quality of work with customers, the formation of demand, 
the creation and reporting of marketing information to consumers (internal and external), and as a result their loyalty to the enterprise (both as to the enterprise rendering services and as to the employer) and services offered by it depend on the personnel.

\section{Literature Survey}

In the modern sense, recruitment services are a type of business focused on search, hiring and personnel management.

The performance appraisal is one of the key elements of a business management system (Hilorme, T., \& Shachanina, Y. (2017)).

The performance indicators of the enterprise rendering services are used to assess the established relationship between the result and the goals (Performance appraisal of personnel is a comprehensive procedure for determining personnel performance based on measuring the individual performance of each employee and his/her level of competence (Hilorme, T., Perevozova, I., Shpak, L., Mokhnenko, A. \& Korovchuk, Yu. (2019), Hilorme, T., Zamazii, O., Judina, O., Korolenko, R. \& Melnikova, Yu. (2019)).

Blacksmith, N., Willford, J.C., \& Behrend, T.S. (2016) characterize recruiting as a professional paid recruitment service for an employing company, provided by an independent commissioned structure. Such structures help the employing company to select highly qualified managerial and working personnel and to create a personnel reserve.

At present, recruitment is an obligatory and necessary process: the quality and effectiveness of which directly affect the performance of the enterprise (Drobyazko, S., Hryhoruk, I., Pavlova, H., Volchanska, L., Sergiychuk, S. (2019)). According to the Palmen Institute (consulting firm), more than $90 \%$ of all
American companies use recruitment today (Davis, T., Cutt, M., Flynn, N., \& Mowl, P. (2016)).

O'Neill, T. A., Lewis, R. J., Law, S. J., Larson, N., Hancock, S., Radan, J., ... \& Carswell, J. J. (2017) offer a general scheme of action for HR managers in the selection of the necessary personnel. Its key structural elements are: determination of the needs of the enterprise-service customer; development optimization of the selection procedures and their payback; standards setting for hiring decisions; development of opportunities for continuous improvement. Such approach allows you to determine in advance the prospects for professional achievements of candidates for the position, helps the company to cope with difficulties, to achieve success and to develop (Darawong, C. (2017)).

The main tasks of modern recruitment are as follows: tasks related to the customer services namely; search and selection of personnel in accordance with the requirements of the employer, confidentiality of search, reliability of selection (responsibility and guarantees) (Roulin, N. (2016)), and selection in a strictly stipulated by a contract period; tasks related to the recruitment agency namely; profitability and performance of activities (Viswesvaran, C., \& Ones, D. S. (2017)), search and training of own personnel, creation of the name and promotion of the brand in the market of personnel services; and tasks for the formation of a civilized labor market namey; having an alternative to the state employment service, research on the dynamics and trends of the labor market, salary levels, personnel requirements, consultations of enterprises and applicants on personnel issues (Salgado, J. F., \& De Fruyt, F. (2017)) etc.

\section{Methods}

The theoretical and methodological basis of the work is a set of gnoseological 
approaches, the laws of dialectical logic in the formulation of a scientific hypothesis and the construction of conclusions, general scientific and special methods of scientific knowledge. The most theoretical results were obtained using a systematic approach to the study of complex economic phenomena and processes in their interrelation and interdependence.

The use of this method, using tools such as business simulation, analytical case, specialized tests and questionnaires, individual interviewing on competencies, allows: accurately assessing the level of competence of contact personnel and managers of the enterprise; identifying promising employees with high creative potential for their further development and movement upwards in the hierarchy of the positions; carrying out an optimal personnel distribution within the enterprise; developing individual plans for the development of contact personnel, taking into account its strengths and weaknesses; organizing up-to-date personnel training and forming a personnel reserve of an enterprise, etc.

In the second case, when assessing the level and quality of the contact personnel's work, it is advisable to use:

1. KPI method (Key Performance Indicators (KPI)). The results of the work of a specific employee with clearly defined indicators (minimum, target and maximum values) in quantitative (time, number of services provided, amount of profit, etc.) and qualitative (level of competence, quality of service, number of repeated calls and recommendations) meanings are subject to assessment (Stevenson, B. S., \& Fowler, C. H. (2016)). The use of the KPI method allows building a balanced system of the enterprise performance management, based on the achievement of its strategic goals.

2. MBO method (Management By Objectives (MBO) - management system using objectives). This method is based on the basis of SMART - criteria for setting goals and objectives for a specific employee or structure (Malshe, A., Johnson, J. S., \& Viio, P. (2017))). Accordingly, goals must be specific and clear, measurable, realistic and achievable, result-oriented and timebound. Based on the results obtained, the most successful employees are encouraged, and measures are developed to improve the performance of contact personnel for the future.

3. BARS method (Behaviorally Anchored Rating Scale). This method is used to assess the compliance of employee behavior with the established rules and standards that are developed and used in the enterprise (Hilorme, T., Shurpenkova, R., Kundrya-Vysotska, O., Sarakhman, 0., Lyzunova, O. (2019)). Thus, this method is particularly relevant in the assessment of the contact personnel's behavior. Also BARS-method can be used in the process of formation and development of the corporate culture of the enterprise.

4. Universal Standards Method. Universal performance standards are developed on the basis of three key parameters: the volume of tasks to be performed and position responsibilities, the term for tasks and functions completion, and the quality of their performance (Drobyazko, S. (2018a)).

\section{Results}

The activities of modern recruiting agencies include the provision of a wide range of services, in particular personnel consulting services, organization of training and adaptation, assessment and certification of enterprise personnel, brand formation of an enterpriseemployer, advice on career planning, drafting and placement of applications, interviewing, psychological and professionally orientated testing and the like. The quality of personnel recruitment 
depends on what technologies are used by recruiters.

The following recruitment technologies are distinguished:

1. Screening. Personnel recruitment is carried out according to formalized characteristics: education, age, gender, work experience, and the like. As a result, the customer directly selects the candidates from the received resumes provided to him by the agency, and the recruiter acts as the supplier of the relevant candidates (Borodai, V. A. (2017));

2. Executive Search. Executive Search - professional method of recruiting senior managers, taking into account the characteristics of the customer's business, workplace, business and personal qualities of the candidate;

3. Head hunting. This is a way to search for candidates on middle and top manager positions (key specialists). Search for specific candidates is carried out in pre-defined companies, from which the customer wants to "pull out" personnel. (Drobyazko, S. (2018b));

4. Selection Recruitment - is an in-depth selection taking into account the professional experience, business and personal qualities of the candidate, it is carried out on a database of candidates and feedbacks on vacancy announcements that are posted in specialized media and on Internet sites. (Gunderson, E. E. (2017));

5. Executive Recruitment. This is a relatively new technology, which is based on the Executive Search method of high quality candidates search on different positions;

6. Graduate Recruitment. The main task is to provide consulting, marketing and recruiting services aimed at effective work with an audience of university graduates (Salgado, J. F. (2016));

7. Permanent Recruitment - it is a service that provides a constant support by a recruiter of a certain company with the knowledge of the specifics of its activities and specific requirements for applicants (Olson, E. M., Slater, S. F., Hult, G. T. M., \& Olson, K. M. (2018)).

The US corporations are using the new concept of development - «top grading» (selection of the best), according to which the difference between competitive and non-competitive enterprises is the ability to first find, hire and promote only the best employees, taking into account their own needs and at the same time getting rid of low-productivity employees (Brady, N. C., Bruce, S., Goldman, A., Erickson, K., Mineo, B., Ogletree, B. T., ... \& Schoonover, J. (2016)). As a result, there is a need for quick and effective selection of the necessary personnel, which actually contributes to the development of recruitment. Thus, the success of modern enterprises in the service sector mainly depends not so much on the strategic plan and technical and technological base, but on the specialists who work in the enterprises. However, we should not forget that a mistake in hiring employees can lead to significant losses for the enterprise. In order to avoid such phenomena, employers significantly toughen the requirements for applicants, especially in the post-crisis period. Therefore, recruiters in addition to traditional tools, use the latest recruiting technologies in the selection of personnel (enhanced verification tests, "black lists" on the Internet, social networking information, making up the applicant's astrological cards).

Recruiting experts believe that an enterprise that offers a social package to potential employees is more likely to attract highly qualified contact personnel and retain it. However, the use of intangible incentives reaches its goal only in the case when the employee receives an appropriate financial reward. Therefore, monitoring wages is also in demand now. In recent years, there has 
been a demand for motivation managers in the labor market, whose duties include finding out how competitive the working conditions at a particular enterprise are and how efficient the work of contact personnel is. The use of the recruitment allows analyzing opportunities and threats, strengths and weaknesses of both enterprises and personnel, identifying key features of businesses in the portfolio, and determining areas of strategic development in order to conquer new and to retain existing customers (internal and external), building mutually beneficial and long-term partnerships with them. Accordingly, the rational distribution and the use of available labor resources allow balancing the interests of the shareholder, personnel and consumers, and increasing the performance indicators.

High performance of recruitment to ensure effective internal marketing of the enterprise in the service sector can be achieved by adapting contact personnel to the internal environment of the enterprise-employer at the stage of searching, hiring and training personnel for working at it. The main objective of recruitment is to select such an applicant for a position in which he will maximally meet its requirements, easily flow into business processes without wasting time on prolonged adaptation and training, in addition to being customer-oriented, loyal and able to perceive the corporate mission and values of the enterpriseemployer.

Contact personnel in the internal marketing system allows providing high quality service at all stages of its interaction with the consumer, starting from the first contact, which influences the formation of the system of expectations and impressions, continuing to create and provide services, that is, organizing and implementing the service process, ending with customer support and the formation of his/her loyalty.
Thus, if the employee is satisfied with the working conditions, the salary, the atmosphere in the team, the opportunity to realize the potential etc., the motivation of the contact personnel is increased. Based on this, recruitment can be considered as an effective tool that precedes quality management (work, services, maintenance, etc.), in a certain way that influences the performance indicators of both the enterprise and the personnel. Accordingly, if the enterprise requesting recruiting services is satisfied with their quality, the vacancy is considered to be filled.

The next stage is the development of methods and principles for building partnership relations between the company's management and contact personnel. This allows, firstly, developing the most acceptable line of conduct for management with contact personnel, and secondly, ensuring effective management of the enterprise in a tactical and strategic period.

An important prerequisite for ensuring effective operational activity of the enterprise and achieving synergy is the creation of a system of relations with staff based on the competence approach, starting with the stage of a candidate selection for the position, its rotation, and ending with dismissal.

After the selection of contact personnel and involving it in operating activities, it is advisable to build prospects for its development in the enterprise, which is based on the methodology of drawing a life-cycle curve. For front-office contact personnel, middle and top managers of the top office, it is advisable to develop individual life-cycle curves.

Separately, when making an assessment, it is reasonable to determine the potential rating of the contact personnel. It is not an assessment of current activities, but an assessment of the future advancement of an employee in order to build an 
individual career plan. An equally important element in building relationships between the company's top management and contact personnel is the staff reduction process, or the outplacement system, which provides analyzing candidates who are dismissed, conducting their psychological support and facilitating further employment. Providing employment for dismissed personnel allows avoiding the transfer of personnel to competitors that are not consciously included in the list of potential employers. Staff reduction on the marketing basis will allow forming an external personnel reserve and using it in a consulting or leasing basis.

Building a mutually beneficial partnership of top management with contact personnel allows the enterprise to achieve the corporate goal. Therefore, the combination of knowledge of the market situation and the requirements of the quality of employees allows the company's management to develop priority areas of work with personnel, with a focus on achieving a positive overall result.

\section{Discussion}

The employee's entry into the professional burnout zone is confirmed by a decrease in his efficiency, degradation in loyalty, lack of satisfaction with work, decrease in labor productivity and degradation in teamwork. In order to prevent the occurrence of professional burnout, systematic diagnosis of contact personnel is necessary. Preventive marketing activities or events in detecting the first signs of burnout are behavior monitoring and evaluation, training, rotation with the purpose of work, change in team and responsibilities fnd delegation of additional powers and responsibilities. Thanks to such measures, it is possible to prevent the burnout of a highly qualified and competent employee, prolong his/her life cycle, and keep him/her in the enterprise. As a result of the implementation of the proposed measures, it is possible to prolong the location of an employee in the professional implementation zone, increasing his/her performance and effectiveness. If the employee is in a zone of professional burnout or professional stagnation, then it is better to dismiss such an employee, in most cases. At this stage, the employee is already lost for the internal market, but may be a new force on the external labor market. The timing of the duration of each of the stages of the life cycle of contact personnel is advisable to determine purely individually, taking into account the specifics of work, areas of responsibility, level of competence, and the like.

The introduction of the mentoring and coaching system will minimize the risks associated with undesirable behavior of personnel. It will strengthen the team closeness, motivate employees to improve the efficiency of their professional activities, and positively manage change.

We consider it expedient to adapt for introduction at the service sector enterprises:

- GROW coaching models (Goal, Reality, Options, Way /Will);

- «TSD» mentoring models (Tell, Show, Do).

The first model is a four-level structure, which consists of the following elements: Goal - short and long term goal setting; Reality - survey of the current situation into reality; Options - defining a list of opportunities and action plan strategies; Way/Will - intentions, "what, when, by whom and for what?" will be made.

In practical terms, it is advisable to develop forms with a list of questions within the coaching program for the implementation of this model. The basis of this model, which confirms its 
feasibility, is precisely the questions, the answers to which will force the employee to use creativity and form their own style in decision making, interaction with colleagues and clients, and management, rather than to duplicate the recommendations of mentors (Hilorme, T., Nazarenko I., Okulicz-Kozaryn, W., Getman, O. \& Drobyazko, S. (2018)).

In the second model, the mentor clearly formulates the objectives of training and outlines the range of questions that the employee must have after training: Tell step-by-step explanation of tasks for the trainee; Show - demonstration of the way of performing the task with the comments; Do - an employee independently performs the tasks. After the completion of training, the mentor sets feedback with the employee and reports the criteria for assessment of the skills acquired.
Depending on the class and type of services provided by the enterprise, in addition to the other named characteristics, special attention should be paid to the assessment of the psychophysiological data of the contact personnel, which greatly influences the development and mental manifestations of the personality. Here we are talking about anthropometric indicators - age, gender, health status, appearance features, speech characteristics, neuroemotional stability, etc. Therefore, in order to diagnose the visual and verbal features of contact personnel, we suggest using the semantic differential technique. This will allow to carrying out an integral description of the front-office contact personnel according to the complex of its psycho-physiological, voice and speech signs, activity, emotional expressiveness, intelligence, and the like (Table 1).

Table 1: The list of subjective scales of semantic differential assessment of contact personnel on personal characteristics

\begin{tabular}{|l|c|c|c|c|c|c|c|l|}
\hline \multicolumn{1}{|c|}{ Factor of psycho-physiological features } \\
\hline Ugly & -3 & -2 & -1 & 0 & 1 & 2 & 3 & Beautiful \\
\hline Unpleasant & -3 & -2 & -1 & 0 & 1 & 2 & 3 & Pleasant \\
\hline Irritable & -3 & -2 & -1 & 0 & 1 & 2 & 3 & Equable \\
\hline Mannered & -3 & -2 & -1 & 0 & 1 & 2 & 3 & Untutored \\
\hline \multicolumn{8}{|c|}{ Activity factor (temperament) } \\
\hline Inert & -3 & -2 & -1 & 0 & 1 & 2 & 3 & Vigorous \\
\hline Slow & -3 & -2 & -1 & 0 & 1 & 2 & 3 & Impetuous \\
\hline Passive & -3 & -2 & -1 & 0 & 1 & 2 & 3 & Active \\
\hline \multicolumn{7}{|c|}{ Factor of emotional expressiveness, expression } \\
\hline Silent & -3 & -2 & -1 & 0 & 1 & 2 & 3 & Flexible \\
\hline Monotonous & -3 & -2 & -1 & 0 & 1 & 2 & 3 & Impressive \\
\hline Restrained & -3 & -2 & -1 & 0 & 1 & 2 & 3 & Expressive \\
\hline Sluggish & -3 & -2 & -1 & 0 & 1 & 2 & 3 & Cheerful \\
\hline \multicolumn{8}{|c|}{ Factor of intelligence (thinking) } \\
\hline Vulgar & -3 & -2 & -1 & 0 & 1 & 2 & 3 & Intelligent \\
\hline Frivolous & -3 & -2 & -1 & 0 & 1 & 2 & 3 & Serious \\
\hline Empty & -3 & -2 & -1 & 0 & 1 & 2 & 3 & Full \\
\hline Irrational & -3 & -2 & -1 & 0 & 1 & 2 & 3 & Rational \\
\hline
\end{tabular}


The author's research experimentally established that the differential scales work according to the principle of homogeneous grouping, which will later allows considering the subjective semantic space of features-factors. Neglecting the determination of the psycho-physiological features of the contact personnel involved in the services sector can lead to a number of problems. In particular, non-standard height, untidy appearance, or discrepancy on weight category, unusual pitch of voice and other characteristics of emotional expressiveness can interfere with the establishment of verbal contact or effective negotiation. At the same time, the employee may be highly qualified, customer-oriented and competent.

But, in our opinion, it is the demotivation factors that influence the loyalty and productivity of personnel. Therefore, in addition, a snap poll of contact personnel on demotivation factors was conducted on the author's method. The results are presented in Table 2.

Table 2: Main reasons for personell demotivation

\begin{tabular}{|c|c|c|c|}
\hline $\begin{array}{c}\text { No. } \\
\text { in } \\
\text { seq. }\end{array}$ & Demotivation reasons & $\begin{array}{l}\text { Motivator map, } \\
\text { personal } \\
\text { characteristics } \\
\end{array}$ & Possible actions \\
\hline 1 & Insufficient salary level & $\begin{array}{l}\text { An employee is } \\
\text { focused only on } \\
\text { material incentives. }\end{array}$ & $\begin{array}{l}\text { It is desirable to form another } \\
\text { motivator (bonus and anti-bonus } \\
\text { system) }\end{array}$ \\
\hline 2 & $\begin{array}{l}\text { Absence of non-state } \\
\text { pension insurance }\end{array}$ & $\begin{array}{l}\text { An employee needs } \\
\text { protection in case of } \\
\text { reduced } \\
\text { capacity }\end{array}$ & $\begin{array}{l}\text { To form a system of non-state } \\
\text { pension insurance }\end{array}$ \\
\hline 3 & $\begin{array}{l}\text { Ignoring professional } \\
\text { skills and knowledge, } \\
\text { the complexity of the } \\
\text { work performed, } \\
\text { education }\end{array}$ & Keen sense of justice & $\begin{array}{l}\begin{array}{l}\text { Revision of personnel } \\
\text { qualification } \\
\text { assessment, } \\
\text { changes in the form (or system) } \\
\text { of remuneration }\end{array}\end{array}$ \\
\hline 4 & $\begin{array}{l}\text { Lack of criteria for } \\
\text { employee performance } \\
\text { assessment }\end{array}$ & Keen sense of justice & $\begin{array}{l}\text { Formation of a system for } \\
\text { employee incentive assessment }\end{array}$ \\
\hline 5 & $\begin{array}{l}\text { Unilateral procedure for } \\
\text { reviewing the terms of } \\
\text { payment and incentives }\end{array}$ & Keen sense of justice & $\begin{array}{l}\text { In the formation of a system for } \\
\text { employee incentive assessment - } \\
\text { to increase the objectivity of } \\
\text { results }\end{array}$ \\
\hline 6 & Lack of career growth & $\begin{array}{l}\text { An employee is } \\
\text { focused on } \\
\text { professional growth, } \\
\text { an interesting job }\end{array}$ & $\begin{array}{l}\text { Analysis of the employee's } \\
\text { activities, career growth (if } \\
\text { possible), development of new } \\
\text { technologies, salary increase, } \\
\text { development and training, } \\
\text { recognition }\end{array}$ \\
\hline 7 & $\begin{array}{l}\text { Qualification } \\
\text { mismatch }\end{array}$ & $\begin{array}{l}\text { Self-realization, } \\
\text { stability }\end{array}$ & Internal employee rotation \\
\hline 8 & $\begin{array}{l}\text { Relationship } \\
\text { management }\end{array}$ & $\begin{array}{l}\text { Relationships, team, } \\
\text { atmosphere }\end{array}$ & \begin{tabular}{lcc} 
Formation & of \\
corporate & culture & \multicolumn{2}{c}{ positive } \\
in the
\end{tabular} \\
\hline
\end{tabular}




\begin{tabular}{|c|l|l|l|}
\hline & & & $\begin{array}{l}\text { enterprise identification of } \\
\text { problem areas search for } \\
\text { solutions and their } \\
\text { implementation }\end{array}$ \\
\hline 9 & Teamwork & $\begin{array}{l}\text { Orientation to the } \\
\text { person of the chief }\end{array}$ & $\begin{array}{l}\text { Objective personnel assessment } \\
\text { by management (lack of " } \\
\text { favorites") }\end{array}$ \\
\hline 10 & Constant stress loads & $\begin{array}{l}\text { Stability, hygiene } \\
\text { factors }\end{array}$ & $\begin{array}{l}\text { Load redistribution; improving } \\
\text { the objectives of the enterprise; } \\
\text { professional development, } \\
\text { rotation, professional growth }\end{array}$ \\
\hline 12 & $\begin{array}{l}\text { Harmful } \\
\text { conditions } \\
\text { Problems of personal }\end{array}$ & $\begin{array}{l}\text { Pay attention to the condition of } \\
\text { working places, the location of } \\
\text { the company, etc. }\end{array}$ \\
\hline 13 & $\begin{array}{l}\text { Willing to do own } \\
\text { business }\end{array}$ & $\begin{array}{l}\text { An employee is practically } \\
\text { beyond control, motivation is } \\
\text { possible if it is a manager (high } \\
\text { ambitions and inability to work } \\
\text { under pressure are very likely) }\end{array}$ \\
\hline
\end{tabular}

The main disadvantage of the existing economic incentive mechanism for personnel in enterprises is that employees do not feel the existing incentive system at all, which results, as previously determined, in a high turnover of employees. Thus, we can make the following conclusions: $78.3 \%$ of respondents do not want to work in the enterprise because of the insufficient, in their opinion, salary level, especially against the background of ignoring professional skills and knowledge, complexity of work performed, education received (53.3\%); lack of criteria for assessment of the activities of employees (50\%); unilateral revision of salary conditions and incentives $(48,3 \%)$.

The reasons for personnel demotivation "relationship of management " and "teamwork" indicate a violation of the socio-psychological climate in an enterprise - lack of a warm and friendly atmosphere, understanding and support, reduced loyalty, and the inclusion of organization members in communication processes and comfort.

\section{Conclusion}

Maintaining the potential of high-level contact personnel and ensuring its sustainable development is achieved by systematic training and development. Personnel training and development should be carried out using the elements of the Performance Management Policy (General Educational Development Program). Within the framework of such a policy, it is advisable to develop an annual GEDP Program for the enterprise as a whole. The implementation of the Program ensures the use of a systematic approach to train and improve the competence of managers at all levels and contact personnel, their training and development, the formation of a reserve.

The main objectives of the enterprise performance management process are: connection of personal goals of an employee with the business strategy of an enterprise by setting SMART goals; strengthening employee engagement in achieving corporate goals; management of personnel performance improvement; 
recognition and promotion of the achievements necessary for the successful fulfillment of any role; determination and provision of opportunities for development; acting as a "radar for talents" at the enterprise; strengthening one's own responsibility for personal development; other personnel processes influencing; promotion of changes and the like.

The study substantiates that human resources are undoubtedly a key factor in the success of enterprises operating in the service sector. Highly qualified, satisfied, customer-oriented and loyal personells who loves their work and efficiently perform tasks, are able to provide the company with long-term success in the market. In support of this thesis, a methodology for conducting a marketing audit was applied to personell, which involves study in two directions: personal resource assessment (intellectual, communicative and creative potential, level of responsibility, ability to learn, emotional intelligence, individual values and other qualities); assessment of the current state of contact personnel (assessment of the level of job satisfaction, loyalty both to the services and to the company that provides them, the state of internal motivation, psychoemotional state, professional burnout syndrome, the value or threat of personnel to the business in the future, etc.).

It is proved that the high quality of services only does not guarantee the enterprise long-term mutually beneficial relations with the client. Modern enterprises and service providers, in order to quickly respond to changing business conditions and ensure revenue growth need to constantly improve the mechanisms for building and maintaining long-term mutually beneficial relationships with all participants in the consumer value chain through the effective use of marketing communications. This contributes, firstly, to convey corporate values to all personnel and contact audiences of the enterprise; secondly, it allows assessing the level of awareness of the strategic vision and a clear understanding of tactical tasks by client-oriented contact personnel, who, using effectively a set of competencies, can contribute to improve the business performance; thirdly, it allows achieving the best satisfaction of the needs of consumers who are becoming involved in the process of creating the consumer value of services.

For the organization and implementation of effective operating activities in modern economic conditions, the main task for any enterprise is to optimize the processes of efficient use of available resources, primarily human, which can be achieved only through the implementation of marketing management of the enterprise and personnel. In this regard, the work suggested a complex of internal marketing for service enterprises - "8P", which, unlike the classic marketing complex "7P" (product, price, place, promotion, personnel, process, physical environment), is supplemented by a prolonged service performance. In the proposed approach, taking into account the differences in the process of providing and consuming services depending on the nature of their actions (tangible or intangible actions of the service), the approach to the classification of services was improved taking into account the time factor, namely, services of simultaneous, short-term, prolonged and deferred consumption which were outlined. This will determine how the value of the service in the time dimension will better satisfy the needs of the client.

The prospect of further research is the development of methodological approaches to the complex assessment of contact personnel in achieving the marketing goals of the enterprise. The 
complex assessment of the competencies of contact personnel is a prerequisite for achieving marketing goals and business performance, in addition to beingone of the tools used in the formation of the brand strategy of the service sector enterprise.

\section{References}

1. Blacksmith, N., Willford, J. C., \& Behrend, T. S. (2016). Technology in the employment interview: A meta-analysis and future research agenda.Personnel Assessment and Decisions, 2(1), 2. URL: https://scholarworks.bgsu.edu/pad/vol2 /iss $1 / 2$ /

2. Borodai, V. A. (2017). Simulation assessment center in the service of the company as a factor in the accuracy and validity of the information about the employee. International Journal of Professional Science, (1). URL: https://cyberleninka.ru/article/n/simula tion-assessment-center-in-the-service-ofthe-company-as-a-factor-in-the-accuracyand-validity-of-the-information-aboutthe-employee

3. Brady, N. C., Bruce, S., Goldman, A., Erickson, K., Mineo, B., Ogletree, B. T., ... \& Schoonover, J. (2016). Communication services and supports for individuals with severe disabilities: Guidance for assessment and intervention.American journal on intellectual and developmental disabilities, 121(2), 121-138. URL: http://www.aaiddjournals.org/doi/abs/1 0.1352/1944-7558-121.2.121

4. Darawong, C. (2017). Conflict management styles and interpersonal conflict between marketing and R\&D personnel during the new product development process. International Journal of Innovation and Technology Management, 14(06), 1750034. URL: https://www.worldscientific.com/doi/ab s/10.1142/S0219877017500341
5. Davis, T., Cutt, M., Flynn, N., \& Mowl, P. (2016). Talent assessment: A new strategy for talent management. Routledge. URL: https://www.taylorfrancis.com/books/9 781317046905

6. Drobyazko, S. (2018a). Accounting management of enterprises' own of in the conditions of legislative changes. Economics and Finance, 10, 4-11. URL: http://ecofin.at.ua/maket_ehkonomika_i_ finansy_06_2018.pdf

7. Drobyazko, S. (2018b). Features of tourism services accounting structuring in the information-oriented society. Economics and Finance, Volume, 6, 44-49. URL:

http://ecofin.at.ua/maket_ehkonomika_i_ finansy_10_2018.pdf

8. Drobyazko, S., Hryhoruk, I., Pavlova, H., Volchanska, L., Sergiychuk, S. (2019). Entrepreneurship Innovation Model for Telecommunications Enterprises. Volume 22, Issue 2, 2019. URL: https://www.abacademies.org/articles/e ntrepreneurship-innovation-model-fortelecommunications-enterprises8097.html

9. Gunderson, E. E. (2017). Individual behavior in confined or isolated groups. In Man in isolation and confinement (pp. 144-165). Routledge. URL: https://www.taylorfrancis.com/books/e/ 9781351507493/chapters/10.4324\%2F9 780203786574-5

10.Hilorme, T., \& Shachanina, Y. (2017). Staff development as an object of accounting of a social activity of the entity. Economics and Finance, 6, 14-20. URL:

http://ecofin.at.ua/maket ehkonomika i finansy 06 2017.pdf

11.Hilorme, T., Shurpenkova, R., KundryaVysotska, O., Sarakhman, O., Lyzunova, 0. (2019). Model of energy saving forecasting in entrepreneurship. Journal 
of Entrepreneurship Education. Volume 22, Special Issue 1S, 2019. URL: https://www.abacademies.org/articles/ model-of-energy-saving-forecasting-inentrepreneurship-7994.html

12.Hilorme, T., Perevozova, I., Shpak, L., Mokhnenko, A. \& Korovchuk, Yu. (2019). Human Capital Cost Accounting in the Company Management System. Academy of Accounting and Financial Studies Journal. Volume 23, Special Issue 2, 2019. URL:

https://www.abacademies.org/articles/H uman-Capital-Cost-Accounting-in-theCompany-Management-System-15282635-23-SI-2-415.pdf

13.Hilorme, T., Zamazii, O., Judina, 0., Korolenko, R. \& Melnikova, Yu. (2019). Formation of risk mitigating strategies for the implementation of projects of energy saving technologies. Academy of Strategic Management Journal. Volume 18, Issue 3. URL:

https://www.abacademies.org/articles/F ormation-of-risk-mitigating-strategiesfor-the-implementation-of-projects-19396104-18-3-364.pdf

14.Malshe, A., Johnson, J. S., \& Viio, P. (2017). Understanding the salesmarketing interface dysfunction experience in business-to-business firms: A matter of perspective. Industrial Marketing Management, 63, 145-157. URL:

https://www.sciencedirect.com/science/ article/abs/pii/S0019850117303991

15.Olson, E. M., Slater, S. F., Hult, G. T. M., \& Olson, K. M. (2018). The application of human resource management policies within the marketing organization: The impact on business and marketing strategy implementation. Industrial Marketing Management, 69, 62-73. URL: https://www.sciencedirect.com/science/ article/abs/pii/S0019850118300440
16.0'Neill, T. A., Lewis, R. J., Law, S. J., Larson, N., Hancock, S., Radan, J., ... \& Carswell, J. J. (2017). Forced-choice preemployment personality assessment: Construct validity and resistance to faking. Personality and Individual Differences, 115, 120-127. URL: https://www.sciencedirect.com/science/ article/pii/S0191886916302306

17.Roulin, N. (2016). Individual differences predicting impression management detection in job interviews. Personnel Assessment and Decisions, 2(1), $1 . \quad$ URL: https://scholarworks.bgsu.edu/pad/vol2 /iss1/1/

18.Salgado, J. F. (2016). A theoretical model of psychometric effects of faking on assessment procedures: Empirical findings and implications for personality at work. International Journal of Selection and Assessment, 24(3), 209-228. URL: https://onlinelibrary.wiley.com/doi/abs/ 10.1111/ijsa.12142

19.Salgado, J. F., \& De Fruyt, F. (2017). Personality in personnel selection. The Blackwell handbook of personnel selection, 174-198.

URL: https://onlinelibrary.wiley.com/doi/abs/ 10.1002/9781405164221.ch8

20.Stevenson, B. S., \& Fowler, C. H. (2016). Collaborative assessment for employment planning: Transition assessment and the discovery process. Career Development and Transition for Exceptional Individuals, 39(1), 57-62. URL: https://journals.sagepub.com/doi/abs/1 $0.1177 / 2165143415619151$

21.Viswesvaran, C., \& Ones, D. S. (2017). Job performance: Assessment issues in personnel selection. The Blackwell handbook of personnel selection, 354-375. URL:

https://onlinelibrary.wiley.com/doi/abs/ 10.1002/9781405164221.ch16 